\title{
Crystallographic study of the energetic salt 1,2,4-triazolium perchlorate
}

\section{Mieko Kumasaki, Saori Gontani, Kanae Mori, Shinya Matsumoto and Kazuki Inoue}

Acta Cryst. (2021). C77, 197-201

\section{IUCr Journals CRYSTALLOGRAPHY JOURNALS ONLINE}

Copyright (C) International Union of Crystallography

Author(s) of this article may load this reprint on their own web site or institutional repository provided that this cover page is retained. Republication of this article or its storage in electronic databases other than as specified above is not permitted without prior permission in writing from the IUCr.

For further information see https://journals.iucr.org/services/authorrights.html 


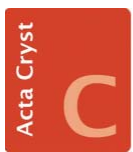

STRUCTURAL

CHEMISTRY

ISSN 2053-2296

Received 17 November 2020

Accepted 26 March 2021

Edited by A. Sarjeant, Bristol-Myers Squibb, USA

Keywords: 1,2,4-triazolium; perchlorate; crystal structure; protonated triazole ring; two-dimensional molecular sheets; green energetic salt; nitrogen-rich azole.

\section{CCDC reference: 1999346}

Supporting information: this article has supporting information at journals.iucr.org/c

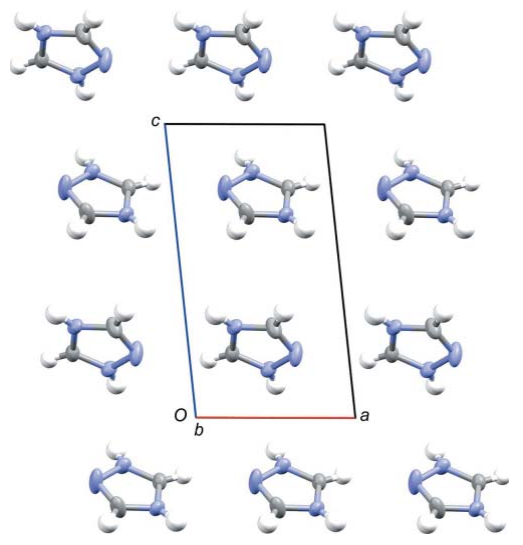

C 2021 International Union of Crystallography

\section{Crystallographic study of the energetic salt 1,2,4- triazolium perchlorate}

\author{
Mieko Kumasaki,* Saori Gontani, Kanae Mori, Shinya Matsumoto and Kazuki Inoue
}

Yokohama National University, 79-7 Tokiwadai, Hodogaya-ku, Yokohama 240-8501, Japan. *Correspondence e-mail: kumasaki@ynu.ac.jp

The molecular and crystal structure of 1H-1,2,4-triazolium perchlorate, $\mathrm{C}_{2} \mathrm{H}_{4} \mathrm{~N}_{3}{ }^{+} \cdot \mathrm{ClO}_{4}{ }^{-}$, was determined as detailed crystallographic data had not been available previously. The structure has monoclinic $\left(P 2_{1} / m\right)$ symmetry. It is of interest in the field of energetic compounds because nitrogen-rich azoles are the backbone of high-density energetic compounds, and salt-based energetic materials can exhibit preferential energy-release behaviour. The bond angles of the 1,2,4-triazolium cation in this study were similar to those of a cationic triazole ring reported previously and were different from those of the neutral triazole ring. This study contributes to the available data that can be used to analyse the relationship between the structures and properties of energetic materials.

\section{Introduction}

Energetic materials, upon reacting, can release energy in the form of heat, gas expansion and shock waves. For a long time, they have been used as explosives, propellants (Damse, 2009) and fireworks. At present, their application has become diverse and has also expanded into the medical sector. For example, energetic materials have been used in a defibrillator device for flash-injecting the conductive gel used for shock delivery in the case of cardiac arrhythmia (Francis \& Reek, 2014). Much effort has been devoted to the design and synthesis of new energetic materials displaying a favourable energy-release behaviour.

Triazoles are a class of energetic material that have gained considerable attention because of their properties, such as stability towards heat and external stimulation, and high nitrogen content (Yu \& Bernstein, 2013; Yin \& Shreeve, 2017). High nitrogen content implies a positive heat of formation and is expected to produce more nitrogen gas per gram than most other high energy materials (Sivabalan et al., 2004; Klapötke et al., 2009.). High nitrogen content also contributes to the formation of conjugated systems that stabilize the molecule, although molecules with high nitrogen content are usually unstable. Thus, triazoles exhibit robustness towards oxidation. They are expected to form energetic salts by accompanying oxidizing anions.

As oxidizing anions such as perchlorate have a high oxygen content, they promote the combustion and gasification of these salts, and the production of small molecules such as $\mathrm{CO}_{2}$ (Da Silva et al., 2013). The amount of residue formed after the combustion and decomposition of these salts is expected to be low. A small amount of residue implies high energy released per unit weight, as well as the favourability of these salts towards the environment (Steinhauser \& Klapötke, 2008).

In this study, we report the synthesis of a green energetic salt, 1,2,4-triazolium perchlorate, (I) (see Scheme), through 
electronic oxidation. Drake et al. (2003) reported 1,2,4-triazolium perchlorate as a new energetic salt with good energy release performance; the synthesis was achieved by mixing 1,2,4-triazole and perchloric acid $\left(\mathrm{HClO}_{4}\right)$. These authors characterised the structure through vibration spectroscopy, multinuclear NMR spectroscopy, differential scanning calorimetry and elemental analysis. They also illustrated its crystal structure by single-crystal X-ray diffraction at $100 \mathrm{~K}$. However, a detailed crystallographic study has not yet been conducted. For further exploration of this type of energetic material, structural information relating to $1 H-1,2,4$-triazolium with oxidizing anions is important.<smiles></smiles>

This report provides a detailed explanation of the crystal structure of $1 H-1,2,4$-triazolium perchlorate synthesized by electronic oxidation. Electronic oxidation is a technique that utilizes the anodic half reaction of a cell to oxidize a given molecule. Crystals suitable for X-ray diffraction analysis were obtained by recrystallization. A sealed-cell differential scanning calorimetric study showed that neutral $1 H-1,2,4$-triazole absorbs heat and releases only a small amount of heat at elevated temperatures. In contrast, the $1 H-1,2,4$-triazolium perchlorate crystal generated a significant amount of heat, which was also more than that generated by the uncrystallized form (Mori et al., 2021).

This article analyses the molecular structure of $1 H-1,2,4-$ triazolium perchlorate by comparing it with the structures of neutral 1,2,4-triazole, analogous molecules and cations. The crystal structure of this salt is compared with that of the chloride salt of $1 H-1,2,4-$ triazolium. The detailed crystallographic data can contribute to the detailed investigation of $1 H-1,2,4$-triazolium perchlorate and the development of highenergy green energetic materials.

\section{Experimental}

\subsection{Synthesis and crystallization}

1,2,4-Triazolium perchlorate was obtained by the electronic oxidation of a solution of 1,2,4-triazole in acetonitrile, following a method described by Fuchigami et al. (2014). 1,2,4Triazole (13.8 g, $0.2 \mathrm{~mol}$; Tokyo Chemical Industry Co. Ltd) and sodium perchlorate ( $30.6 \mathrm{~g}, 0.25 \mathrm{~mol}$; Kanto Chemical Co. Inc.) as the supporting electrolyte were used without further purification and dissolved in acetonitrile $(10 \mathrm{ml}$, FUJIFILM Wako Pure Chemical Corporation) on the anode side of an electrolysis cell. Phenol (18.8 g, $0.2 \mathrm{~mol}$; FUJIFILM Wako Pure Chemical Corporation) was dissolved in acetonitrile on the cathode side for electronic reduction to balance the overall electrical reaction. After a current supply, the solution in the
Table 1

Experimental details.

\begin{tabular}{|c|c|}
\hline \multicolumn{2}{|l|}{ Crystal data } \\
\hline Chemical formula & $\mathrm{C}_{2} \mathrm{H}_{4} \mathrm{~N}_{3}^{+} \cdot \mathrm{ClO}_{4}^{-}$ \\
\hline$M_{\mathrm{r}}$ & 169.53 \\
\hline Crystal system, space group & Monoclinic, $P 2_{1} / m$ \\
\hline Temperature $(\mathrm{K})$ & 223 \\
\hline$a, b, c(\AA)$ & 5.1859 (1), 11.8497 (1), 9.6461 (1) \\
\hline$\beta\left({ }^{\circ}\right)$ & $96.153(1)$ \\
\hline$V\left(\AA^{3}\right)$ & $589.35(1)$ \\
\hline$Z$ & 4 \\
\hline Radiation type & $\mathrm{Cu} \mathrm{K \alpha}$ \\
\hline$\mu\left(\mathrm{mm}^{-1}\right)$ & 5.54 \\
\hline Crystal size $(\mathrm{mm})$ & $1 \times 0.6 \times 0.3$ \\
\hline \multicolumn{2}{|l|}{ Data collection } \\
\hline Diffractometer & $\begin{array}{l}\text { XtaLAB AFC12 (RINC) Kappa } \\
\text { dual home/near }\end{array}$ \\
\hline Absorption correction & $\begin{array}{l}\text { Multi-scan (CrysAlis PRO; Rigaku } \\
\text { OD, 2018) }\end{array}$ \\
\hline$T_{\min }, T_{\max }$ & $0.838,1.000$ \\
\hline $\begin{array}{l}\text { No. of measured, independent and } \\
\text { observed }[I>2 \sigma(I)] \text { reflections }\end{array}$ & $3611,1217,1136$ \\
\hline$R_{\text {int }}$ & 0.030 \\
\hline$(\sin \theta / \lambda)_{\max }\left(\AA^{-1}\right)$ & 0.621 \\
\hline \multicolumn{2}{|l|}{ Refinement } \\
\hline$R\left[F^{2}>2 \sigma\left(F^{2}\right)\right], w R\left(F^{2}\right), S$ & $0.035,0.094,1.12$ \\
\hline No. of reflections & 1217 \\
\hline No. of parameters & 108 \\
\hline $\mathrm{H}$-atom treatment & $\begin{array}{l}\mathrm{H} \text { atoms treated by a mixture of } \\
\text { independent and constrained } \\
\text { refinement }\end{array}$ \\
\hline$\Delta \rho_{\max }, \Delta \rho_{\min }\left(\mathrm{e} \AA^{-3}\right)$ & $0.27,-0.75$ \\
\hline
\end{tabular}

Computer programs: CrysAlis PRO (Rigaku OD, 2018), OLEX2.solve (Bourhis et al., 2015), SHELXL2018 (Sheldrick, 2015), OLEX2 (Dolomanov et al., 2009), Mercury (Macrae et al., 2020) and publCIF (Westrip, 2010).

anode side was transferred to a round-bottomed flask and the solvent was removed under reduced pressure. The dried residue was dissolved in a small amount of acetonitrile. Single crystals of $1 H-1,2,4$-triazolium perchlorate formed in the solution maintained at $10{ }^{\circ} \mathrm{C}$ (yield: $11.0 \mathrm{~g}, 12 \%$ ).

The salt did not present a melting point, released $7.14 \mathrm{~kJ} \mathrm{~g}^{-1}$ of heat and exhibited a decomposition temperature of $316.4{ }^{\circ} \mathrm{C}$ (Mori et al., 2021).

\subsection{Refinement}

The structure of the crystal of perchlorate salt (I) was confirmed using single-crystal X-ray analysis at $223 \mathrm{~K}$. The crystal data, data collection and structure refinement details are summarized in Table 1 . Atoms H3 and H5 of the 1,2,4triazole ring were placed in idealized positions with their $U_{\text {iso }}$ values assigned to be 1.2 times the $U_{\text {eq }}$ values of the attached C atoms. These two $\mathrm{H}$ atoms were refined as riding on their carrier atoms, namely, atoms $\mathrm{C} 3$ and $\mathrm{C} 5$, respectively. Atoms $\mathrm{H} 1$ and $\mathrm{H} 4$ were located from difference Fourier maps and were refined isotropically.

\section{Results and discussion}

This study focused on the perchlorate salt of the small neutral 1,2,4-triazole molecule as a fundamental framework which can be extended through its conjugated system to form larger 
Table 2

Neutral and cationic triazole bond lengths $(\AA)$.

\begin{tabular}{lccccc}
\hline Bond & C5-N1 & N1-N2 & N2-C3 & C3-N4 & N4-C5 \\
\hline Neutral & $1.319(1)$ & $1.368(1)$ & $1.310(1)$ & $1.348(1)$ & $1.335(1)$ \\
Cationic & $1.290(1)$ & $1.349(1)$ & $1.291(1)$ & $1.339(1)$ & $1.312(1)$ \\
This study & $1.299(2)$ & $1.352(2)$ & $1.303(3)$ & $1.341(3)$ & $1.321(3)$ \\
\hline
\end{tabular}

molecules with substituent groups. Fig. 1 presents the molecular structure of this salt, where the asymmetric unit includes one 1,2,4-triazole cation and two perchlorate anions each located on an independent mirror plane. Atoms $\mathrm{Cl6}, \mathrm{O} 7$ and $\mathrm{O} 8$ are on the mirror plane at $\left(x, \frac{1}{4}, z\right)$, and atoms $\mathrm{Cl} 10$, O11 and O12 are located on the mirror plane at $\left(x, \frac{3}{4}, z\right)$.

Structural information with respect to the 1,2,4-triazole ring was retrieved from previous studies (Fuhrmann et al., 1997; Moers et al., 1999; Bujak \& Zaleski, 2001, 2002a,b; Claramunt et al. 2001; Jin et al., 2006; Daszkiewicz \& Marchewka, 2012; Daszkiewicz, 2013; Zhang et al., 2018; Bujak, 2015) and the average bond lengths and angles are listed in Tables 2 and 3. The lengths of the cationic and neutral $\mathrm{C} 5-\mathrm{N} 1$ and N4-C5 bonds were significantly different; however, the bond lengths of the title salt were intermediate between the cationic and neutral bond lengths. Moreover, the bond angles of the 1,2,4triazolium cation in this study were typical for cationic triazole rings; specifically, the $\mathrm{C} 5-\mathrm{N} 1-\mathrm{N} 2$ and $\mathrm{C} 3-\mathrm{N} 4-\mathrm{C} 5$ angles were wider and the $\mathrm{N} 4-\mathrm{C} 5-\mathrm{N} 1$ and $\mathrm{N} 2-\mathrm{C} 3-\mathrm{N} 4$ angles were narrower than those of the neutral triazole ring.

Hydrogen bonds are listed in Table 4. With regard to the hydrogen-bonded network, atoms $\mathrm{O} 7$ and $\mathrm{O} 9$ were bonded to $\mathrm{N} 1$, whereas atoms $\mathrm{O} 8$ and $\mathrm{O} 13$ interacted with $\mathrm{N} 4$; moreover, expansion of the network led to the formation of twodimensional hydrogen-bonded sheets that were slightly undulating and parallel to the $a b$ plane (Fig. 2).

The hydrogen-bond lengths for 1,2,4-triazolium salts were different, whereas the intermolecular $\mathrm{N}-\mathrm{H} \cdots \mathrm{N}$ distance for neutral 1,2,4-triazole was constant at $2.812 \AA$ (Fuhrmann et al., 1997). As intermolecular distances reflect the interactions between molecules, the linkage through perchlorate ions can contribute to the disappearance of the melting point. For the title 1,2,4-triazolium salt, the melting point disappeared, whereas neutral 1,2,4-triazole melted at approximately $124{ }^{\circ} \mathrm{C}$. A detailed analysis of energetic materials requires the accumulation of sufficient data relating to structure and properties.

To analyse the characteristic features of the title perchlorate salt, we compared its structure with that of $1 H$-1,2,4-triazolium chloride, a salt featuring the same cation but a different anion (Bujak \& Zaleski, 2001). The title perchlorate salt presented a monoclinic crystal structure with the space group $P 2_{1} / m$ and

Table 3

Neutral and cationic triazole bond angles $\left(^{\circ}\right)$.

\begin{tabular}{llllll}
\hline Angles & $\mathrm{N} 4-\mathrm{C} 5-\mathrm{N} 1$ & $\mathrm{C} 5-\mathrm{N} 1-\mathrm{N} 2$ & $\mathrm{~N} 1-\mathrm{N} 2-\mathrm{C} 3$ & $\mathrm{~N} 2-\mathrm{C} 3-\mathrm{N} 4$ & $\mathrm{C} 3-\mathrm{N} 4-\mathrm{C} 5$ \\
\hline Neutral & $110.3(1)$ & $109.5(1)$ & $102.6(1)$ & $114.9(1)$ & $102.7(1)$ \\
Cationic & $107.0(1)$ & $111.7(1)$ & $103.3(1)$ & $111.4(1)$ & $106.6(1)$ \\
This study & $106.52(17)$ & $111.94(17)$ & $103.41(17)$ & $111.04(19)$ & $107.08(16)$ \\
\hline
\end{tabular}
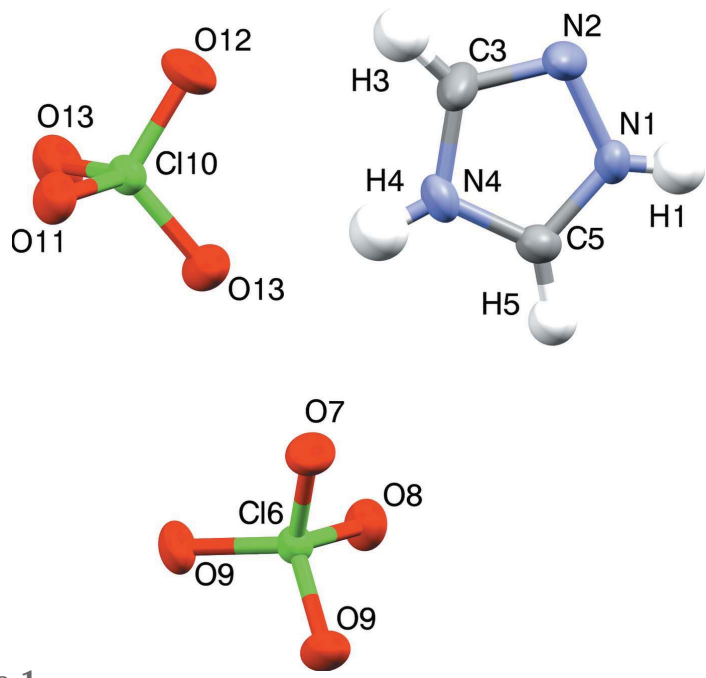

Figure 1

Displacement ellipsoid plot (50\% probability level) of perchlorate salt (I).

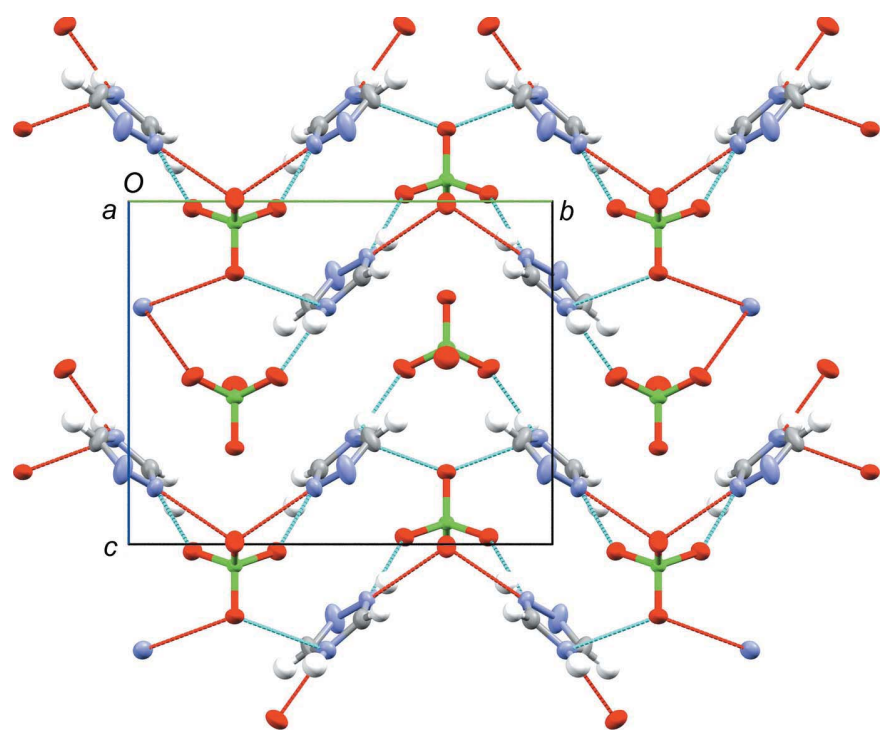

Figure 2

Packing diagram showing the hydrogen-bonded network of perchlorate salt (I).

four molecules in the unit cell. Conversely, the chloride salt presented a monoclinic crystal structure with the space group $P 2_{1} / n$.

The molecular arrangements of the two salts were distinguishable, whereas no significant structural differences were observed between the 1,2,4-triazolium units of the structures. The crystal structures with characteristic molecular arrangements are illustrated in Figs. 3 and 4. For the newly identified perchlorate salt described here, the triazolium ions form a two-dimensional molecular sheet in the $a c$ plane, as illustrated in Fig. 5. In this two-dimensional molecular layer, the triazolium ions form a tilted stack along the $c$ axis, with an interplanar distance of approximately $3.125 \AA$. This layer and the layer consisting of perchlorate ions were symmetrically and alternately aligned along the $b$ axis to form the three-dimensional structure. Therefore, 


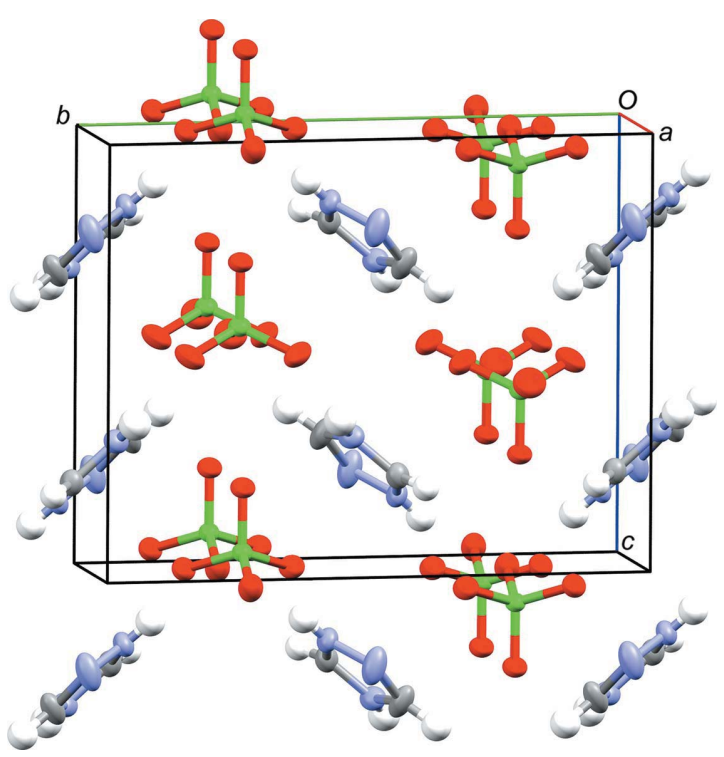

Figure 3

The crystal packing of perchlorate salt (I).

the molecules constituting neighbouring layers were canted by approximately $90^{\circ}$ and the distance between the stacked layers was $5.9249 \AA$, i.e. half the length of the $b$ axis.

In the previously determined chloride salt, the triazolium ions are stacked almost parallel in the form of a brick-wall structure on the $a b$ plane, as shown in Fig. 6. In this twodimensional layer, the interplanar distances between pairs of molecules are 3.166 and $3.281 \AA$. Along the $c$ axis, the twodimensional layers are aligned to form a criss-cross arrangement (Fig. 4). The chloride ions fit in a cavity created by four neighbouring $\mathrm{H}$ atoms, with a shortest distance of $2.331 \AA$. In the case of the perchlorate salt structure, a perchlorate ion being bigger than a chloride ion, the perchlorate ions also form layers located between the layers of triazolium ions.

The newly identified 1,2,4-triazolium perchlorate salt presented a good thermal stability, decomposing at $316.4{ }^{\circ} \mathrm{C}$; the desired decomposition temperature of energetic materials

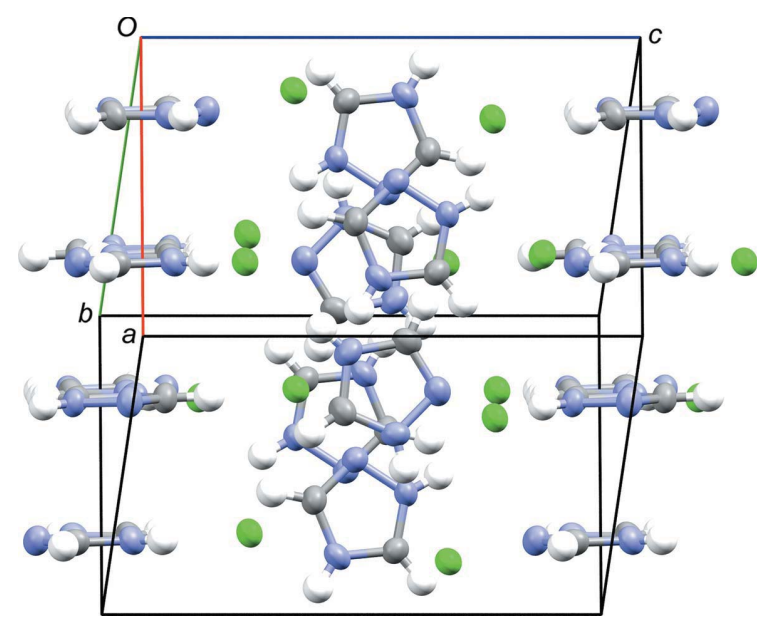

Figure 4

The crystal packing of $1 H$-1,2,4-triazolium chloride for reference.
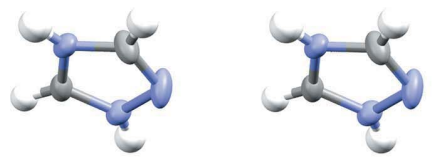<smiles>[Li][Mg]</smiles>
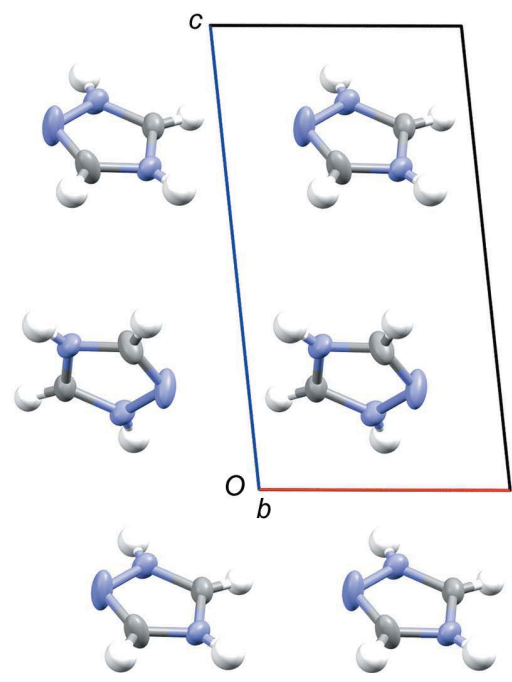$$
\text { ? }
$$
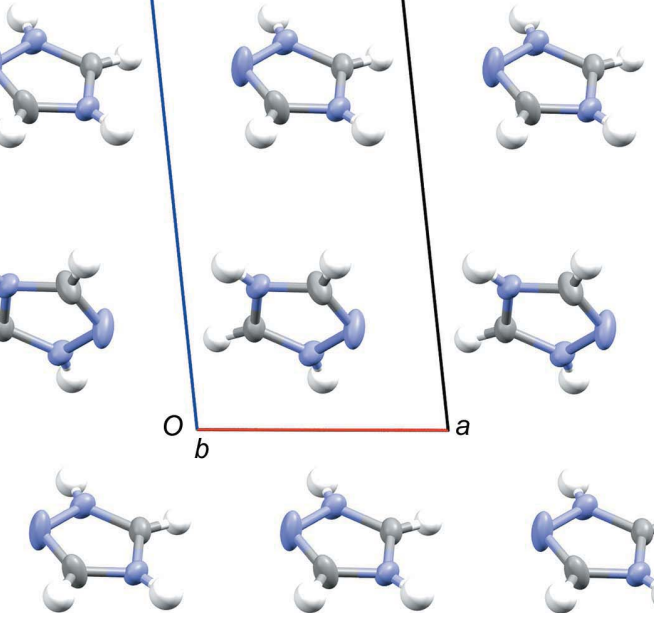

Figure 5

The formation of the two-dimensional sheets in the ac plane for perchlorate salt (I).

is greater than $200{ }^{\circ} \mathrm{C}$ ( $\mathrm{Li}$ et al., 2020). Furthermore, the amount of energy released by 1,2,4-triazolium perchlorate was $7.14 \mathrm{~kJ} \mathrm{~g}^{-1}$, which is significantly greater than for 1,2,4-triazole $\left(0.3 \mathrm{~kJ} \mathrm{~g}^{-1}\right)$ and a mixture of 1,2,4-triazole and sodium perchlorate $\left(3.07 \mathrm{~kJ} \mathrm{~g}^{-1}\right.$ ) (Mori et al., 2021).

Since the triazolium framework of the perchlorate salt exhibited a similar molecular structure to those of positively

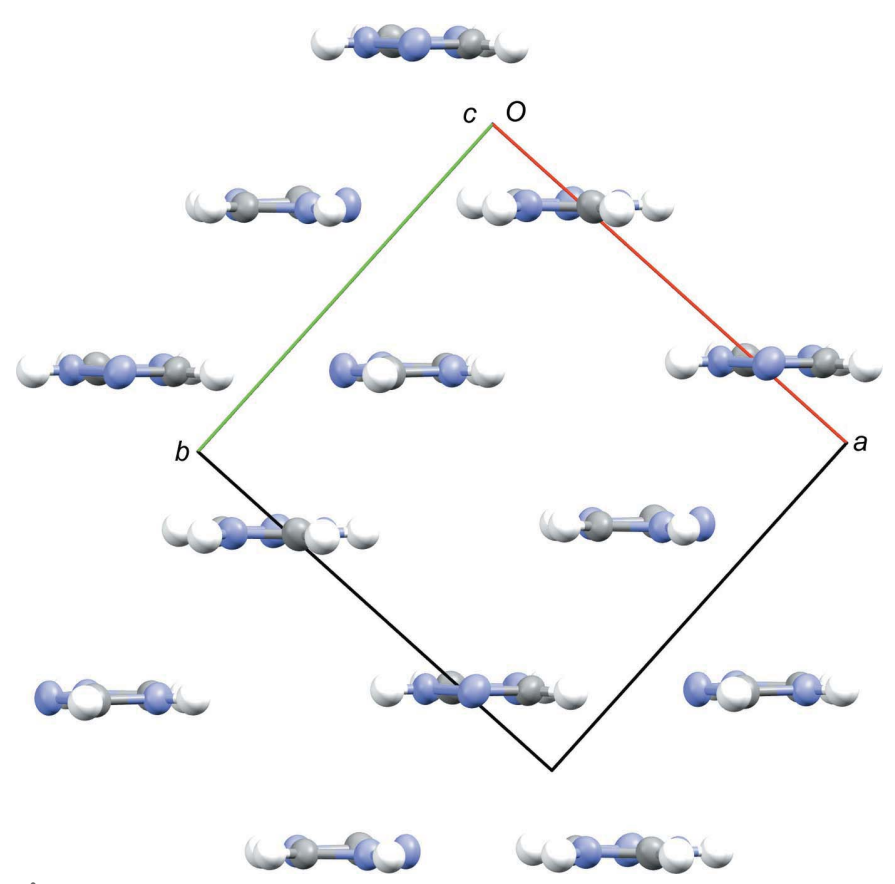

Figure 6

The formation of the brick-wall structure in the $a b$ plane in $1 H-1,2,4-$ triazolium chloride. 
Table 4

Hydrogen-bond geometry $\left(\AA,^{\circ}\right)$.

\begin{tabular}{lllll}
\hline$D-\mathrm{H} \cdots A$ & $D-\mathrm{H}$ & $\mathrm{H} \cdots A$ & $D \cdots A$ & $D-\mathrm{H} \cdots A$ \\
\hline N4-H4 $\cdots$ O13 & 0.818 & 2.141 & 2.921 & 159.61 \\
N1-H1 $\cdots$ O9 & 0.787 & 2.230 & 2.874 & 139.46 \\
N1-H1 $\cdots$ O7 & 0.787 & 2.407 & 2.936 & 125.59 \\
N4-H4 $\cdots$ O8 & 0.818 & 2.719 & 3.049 & 106.14 \\
\hline
\end{tabular}

charged 1,2,4-triazoles which have been determined previously, the structure can be one of the key elements determining the properties. However, structural data accompanied by data relating to properties have been scarce for addressing details of the structure-property relationships of energetic materials. The present study is expected to contribute to this data accumulation and provide a better understanding of what might constitute suitable structures for desired properties.

\section{Acknowledgements}

This study was supported by the Foundation for the Promotion of the Industrial Explosives Technology.

\section{References}

Bourhis, L. J., Dolomanov, O. V., Gildea, R. J., Howard, J. A. K. \& Puschmann, H. (2015). Acta Cryst. A71, 59-75.

Bujak, M. (2015). Polyhedron, 85, 499-505.

Bujak, M. \& Zaleski, J. (2001). Private communication (refcode QULVEY). CCDC, Cambridge, England.

Bujak, M. \& Zaleski, J. (2002a). Main Group Met. Chem. 25, 583-584. Bujak, M. \& Zaleski, J. (2002b). Z. Naturforsch. B, 57, 157-164.

Claramunt, R. M., López, C., Angeles García, M., Dolores Otero, M., Rosario Torres, M., Pinilla, E., Alarcón, S. H., Alkorta, I. \& Elguero, J. (2001). New J. Chem. 25, 1061-1068.

Damse, R. S. (2009). J. Hazard. Mater. 172, 1383-1387.
Da Silva, G., Rufino, S. C. \& Iha, K. (2013). J. Aerosp. Technol. Manag. 5, 267-278.

Daszkiewicz, M. (2013). J. Mol. Struct. 1032, 56-61.

Daszkiewicz, M. \& Marchewka, M. K. (2012). J. Mol. Struct. 1017, 9097.

Dolomanov, O. V., Bourhis, L. J., Gildea, R. J., Howard, J. A. K. \& Puschmann, H. (2009). J. Appl. Cryst. 42, 339-341.

Drake, G., Hawkins, T., Brand, A., Hall, L., Mckay, M., Vij, A. \& Ismail, I. (2003). Propellants Explosives Pyrotech. 28, 174-180.

Francis, J. \& Reek, S. (2014). Indian Heart J. 66, 68-72.

Fuchigami, T., Atobe, M. \& Inagi, S. (2014). Fundamentals and Applications of Organic Electrochemistry: Synthesis, Materials, Devices, pp. 33-43 Chichester: Wiley.

Fuhrmann, P., Koritsánszky, T. \& Luger, P. (1997). Z. Kristallogr. Cryst. Mater. 212, 213-220.

Jin, C.-M., Wu, L.-Y., Chen, C.-Y. \& Hu, S.-L. (2006). Acta Cryst. E62, o4515-o4516.

Klapötke, T. M., Minar, N. K. \& Stierstorfer, J. (2009). Polyhedron, 28, 13-26.

Li, H., Yan, B., Ma, H., Sun, Z., Ma, Y. \& Zhang, Z. (2020). Acta Cryst. C76, 64-68.

Macrae, C. F., Sovago, I., Cottrell, S. J., Galek, P. T. A., McCabe, P., Pidcock, E., Platings, M., Shields, G. P., Stevens, J. S., Towler, M. \& Wood, P. A. (2020). J. Appl. Cryst. 53, 226-235.

Moers, O., Wijaya, K., Jones, P. G. \& Blaschette, A. (1999). Acta Cryst. C55, 1542-1545.

Mori, K., Kumasaki, M. \& Atobe, M. (2021). Sci. Tech. Energetic Materials, In the press.

Rigaku OD (2018). CrysAlis PRO. Rigaku Oxford Diffraction, Yarnton, Oxfordshire, England.

Sheldrick, G. M. (2015). Acta Cryst. C71, 3-8.

Sivabalan, R., Talawar, M. B., Senthilkumar, N., Kavitha, B. \& Asthana, S. N. (2004). J. Therm. Anal. Calorim. 78, 781-792.

Steinhauser, G. \& Klapötke, T. M. (2008). Angew. Chem. Int. Ed. 47, 3330-3347.

Westrip, S. P. (2010). J. Appl. Cryst. 43, 920-925.

Yin, P. \& Shreeve, J. M. (2017). Adv. Heterocycl. Chem. 121, 89-131.

Yu, Z. \& Bernstein, E. R. (2013). J. Phys. Chem. A, 117, 10889-10902.

Zhang, P., Zhao, X., Du, Y., Gozin, M., Li, S. \& Pang, S. (2018). RSC Adv. 8, 24627-24632. 


\title{
supporting information
}

Acta Cryst. (2021). C77, 197-201 [https://doi.org/10.1107/S2053229621003260]

\section{Crystallographic study of the energetic salt 1,2,4-triazolium perchlorate}

\author{
Mieko Kumasaki, Saori Gontani, Kanae Mori, Shinya Matsumoto and Kazuki Inoue
}

Computing details

Data collection: CrysAlis PRO (Rigaku OD, 2018); cell refinement: CrysAlis PRO (Rigaku OD, 2018); data reduction: CrysAlis PRO (Rigaku OD, 2018); program(s) used to solve structure: olex2.solve (Bourhis et al., 2015); program(s) used to refine structure: SHELXL2018 (Sheldrick, 2015) and OLEX2 (Dolomanov et al., 2009); molecular graphics: Mercury (Macrae et al., 2020); software used to prepare material for publication: publCIF (Westrip, 2010).

1H-1,2,4-Triazolium perchlorate

Crystal data

$\mathrm{C}_{2} \mathrm{H}_{4} \mathrm{~N}_{3}{ }^{+} \cdot \mathrm{ClO}_{4}{ }^{-}$

$M_{r}=169.53$

Monoclinic, $P 2_{1} / m$

$a=5.1859$ (1) $\AA$

$b=11.8497(1) \AA$

$c=9.6461(1) \AA$

$\beta=96.153(1)^{\circ}$

$V=589.35(1) \AA^{3}$

$Z=4$

\section{Data collection}

XtaLAB AFC12 (RINC) Kappa dual home/near diffractometer

Radiation source: micro-focus sealed X-ray tube, Rigaku $(\mathrm{Cu}) \mathrm{X}$-ray Source

Mirror monochromator

$\omega$ scans

Absorption correction: multi-scan

(CrysAlis PRO; Rigaku OD, 2018)

$T_{\min }=0.838, T_{\max }=1.000$

Refinement

Refinement on $F^{2}$

Least-squares matrix: full

$R\left[F^{2}>2 \sigma\left(F^{2}\right)\right]=0.035$

$w R\left(F^{2}\right)=0.094$

$S=1.12$

1217 reflections

108 parameters

0 restraints

Primary atom site location: iterative
$F(000)=344$

$D_{\mathrm{x}}=1.911 \mathrm{Mg} \mathrm{m}^{-3}$

$\mathrm{Cu} K \alpha$ radiation, $\lambda=1.54184 \AA$

Cell parameters from 2328 reflections

$\theta=4.6-73.1^{\circ}$

$\mu=5.54 \mathrm{~mm}^{-1}$

$T=223 \mathrm{~K}$

Plate, clear pale yellow

$1 \times 0.6 \times 0.3 \mathrm{~mm}$

3611 measured reflections

1217 independent reflections

1136 reflections with $I>2 \sigma(I)$

$R_{\text {int }}=0.030$

$\theta_{\text {max }}=73.3^{\circ}, \theta_{\min }=4.6^{\circ}$

$h=-6 \rightarrow 6$

$k=-13 \rightarrow 14$

$l=-11 \rightarrow 11$

Hydrogen site location: mixed

$\mathrm{H}$ atoms treated by a mixture of independent and constrained refinement

$w=1 /\left[\sigma^{2}\left(F_{\mathrm{o}}^{2}\right)+(0.0523 P)^{2}+0.1864 P\right]$

where $P=\left(F_{\mathrm{o}}{ }^{2}+2 F_{\mathrm{c}}{ }^{2}\right) / 3$

$(\Delta / \sigma)_{\max }<0.001$

$\Delta \rho_{\max }=0.27$ e $\AA^{-3}$

$\Delta \rho_{\min }=-0.75$ e $\AA^{-3}$ 


\section{Special details}

Geometry. All esds (except the esd in the dihedral angle between two 1.s. planes) are estimated using the full covariance matrix. The cell esds are taken into account individually in the estimation of esds in distances, angles and torsion angles; correlations between esds in cell parameters are only used when they are defined by crystal symmetry. An approximate (isotropic) treatment of cell esds is used for estimating esds involving l.s. planes.

Fractional atomic coordinates and isotropic or equivalent isotropic displacement parameters $\left(\AA^{2}\right)$

\begin{tabular}{lllll}
\hline & $x$ & $y$ & $z$ & $U_{\text {iso }} * U_{\text {eq }}$ \\
\hline C110 & $0.85233(11)$ & 0.750000 & $0.42804(6)$ & $0.0232(2)$ \\
O11 & $0.8685(4)$ & 0.750000 & $0.28056(18)$ & $0.0319(5)$ \\
O12 & $0.5866(4)$ & 0.750000 & $0.4563(2)$ & $0.0416(5)$ \\
O13 & $0.9799(3)$ & $0.65063(13)$ & $0.48852(15)$ & $0.0388(4)$ \\
N1 & $0.5121(3)$ & $0.43779(14)$ & $0.83520(17)$ & $0.0277(4)$ \\
H1 & $0.477(5)$ & $0.391(2)$ & $0.888(3)$ & $0.044(7)^{*}$ \\
N2 & $0.3322(3)$ & $0.51339(16)$ & $0.7827(2)$ & $0.0429(5)$ \\
N4 & $0.6962(3)$ & $0.53346(15)$ & $0.69127(17)$ & $0.0297(4)$ \\
H4 & $0.808(6)$ & $0.561(3)$ & $0.648(3)$ & $0.052(8)^{*}$ \\
C3 & $0.4530(4)$ & $0.57112(19)$ & $0.6944(2)$ & $0.0384(5)$ \\
H3 & 0.379350 & 0.631209 & 0.640211 & $0.046^{*}$ \\
C5 & $0.7300(4)$ & $0.44967(17)$ & $0.7816(2)$ & $0.0288(4)$ \\
H5 & 0.881871 & 0.406992 & 0.803017 & $0.035^{*}$ \\
C16 & $1.03081(10)$ & 0.250000 & $0.06220(5)$ & $0.0209(2)$ \\
O7 & $0.7698(4)$ & 0.250000 & $-0.0070(2)$ & $0.0327(5)$ \\
O8 & $1.0241(4)$ & 0.250000 & $0.21008(18)$ & $0.0319(5)$ \\
O9 & $1.1632(3)$ & $0.34949(12)$ & $0.02056(13)$ & $0.0313(3)$ \\
& & & & \\
\hline
\end{tabular}

Atomic displacement parameters $\left(\AA^{2}\right)$

\begin{tabular}{lllllll}
\hline & $U^{11}$ & $U^{22}$ & $U^{33}$ & $U^{12}$ & $U^{13}$ & $U^{23}$ \\
\hline C110 & $0.0243(3)$ & $0.0267(3)$ & $0.0191(3)$ & 0.000 & $0.0053(2)$ & 0.000 \\
O11 & $0.0459(12)$ & $0.0308(11)$ & $0.0195(9)$ & 0.000 & $0.0058(8)$ & 0.000 \\
O12 & $0.0244(10)$ & $0.0558(15)$ & $0.0464(12)$ & 0.000 & $0.0116(9)$ & 0.000 \\
O13 & $0.0447(8)$ & $0.0410(9)$ & $0.0318(7)$ & $0.0131(7)$ & $0.0096(6)$ & $0.0121(6)$ \\
N1 & $0.0313(8)$ & $0.0227(8)$ & $0.0304(8)$ & $-0.0006(7)$ & $0.0089(7)$ & $0.0045(7)$ \\
N2 & $0.0234(8)$ & $0.0329(10)$ & $0.0742(13)$ & $0.0036(7)$ & $0.0138(8)$ & $0.0147(9)$ \\
N4 & $0.0288(8)$ & $0.0331(9)$ & $0.0286(8)$ & $-0.0067(7)$ & $0.0093(7)$ & $0.0019(7)$ \\
C3 & $0.0275(9)$ & $0.0327(11)$ & $0.0529(13)$ & $-0.0024(8)$ & $-0.0047(9)$ & $0.0169(10)$ \\
C5 & $0.0232(9)$ & $0.0276(10)$ & $0.0356(10)$ & $0.0017(7)$ & $0.0036(7)$ & $-0.0011(8)$ \\
C16 & $0.0233(3)$ & $0.0212(3)$ & $0.0184(3)$ & 0.000 & $0.0034(2)$ & 0.000 \\
O7 & $0.0242(9)$ & $0.0308(11)$ & $0.0416(11)$ & 0.000 & $-0.0044(8)$ & 0.000 \\
O8 & $0.0456(12)$ & $0.0307(11)$ & $0.0207(9)$ & 0.000 & $0.0091(8)$ & 0.000 \\
O9 & $0.0359(7)$ & $0.0309(8)$ & $0.0279(7)$ & $-0.0098(6)$ & $0.0070(5)$ & $0.0023(6)$ \\
& & & & & & \\
\hline
\end{tabular}

Geometric parameters $\left(\AA,{ }^{o}\right)$

\begin{tabular}{llll}
\hline $\mathrm{C} 110-\mathrm{O} 11$ & $1.4341(18)$ & $\mathrm{N} 4-\mathrm{C} 3$ & $1.341(3)$ \\
$\mathrm{C} 110-\mathrm{O} 12$ & $1.433(2)$ & $\mathrm{N} 4-\mathrm{C} 5$ & $1.321(3)$
\end{tabular}




\begin{tabular}{|c|c|c|c|}
\hline $\mathrm{Cl} 10-\mathrm{O} 13^{\mathrm{i}}$ & $1.4428(15)$ & $\mathrm{C} 3-\mathrm{H} 3$ & 0.9400 \\
\hline $\mathrm{C} 110-\mathrm{O} 13$ & $1.4428(15)$ & $\mathrm{C} 5-\mathrm{H} 5$ & 0.9400 \\
\hline $\mathrm{N} 1-\mathrm{H} 1$ & $0.78(3)$ & $\mathrm{Cl} 6-\mathrm{O} 7$ & $1.4438(19)$ \\
\hline $\mathrm{N} 1-\mathrm{N} 2$ & $1.352(2)$ & $\mathrm{Cl} 6-\mathrm{O} 8$ & $1.4305(18)$ \\
\hline $\mathrm{N} 1-\mathrm{C} 5$ & $1.299(2)$ & $\mathrm{Cl} 6-\mathrm{O} 9$ & $1.4428(14)$ \\
\hline $\mathrm{N} 2-\mathrm{C} 3$ & $1.303(3)$ & $\mathrm{Cl} 6-\mathrm{O}^{\mathrm{ii}}$ & $1.4427(14)$ \\
\hline $\mathrm{N} 4-\mathrm{H} 4$ & $0.82(3)$ & & \\
\hline $\mathrm{O} 11-\mathrm{C} 110-\mathrm{O} 13$ & $109.15(8)$ & $\mathrm{N} 2-\mathrm{C} 3-\mathrm{N} 4$ & $111.04(19)$ \\
\hline $\mathrm{O} 11-\mathrm{Cl10}-\mathrm{O} 13^{\mathrm{i}}$ & $109.15(8)$ & $\mathrm{N} 2-\mathrm{C} 3-\mathrm{H} 3$ & 124.5 \\
\hline $\mathrm{O} 12-\mathrm{Cl10}-\mathrm{O} 11$ & $110.38(13)$ & $\mathrm{N} 4-\mathrm{C} 3-\mathrm{H} 3$ & 124.5 \\
\hline $\mathrm{O} 12-\mathrm{C} 110-\mathrm{O} 13$ & $109.38(8)$ & $\mathrm{N} 1-\mathrm{C} 5-\mathrm{N} 4$ & $106.52(17)$ \\
\hline $\mathrm{O} 12-\mathrm{Cl10}-\mathrm{O} 13^{\mathrm{i}}$ & $109.38(8)$ & $\mathrm{N} 1-\mathrm{C} 5-\mathrm{H} 5$ & 126.7 \\
\hline $\mathrm{O} 13-\mathrm{C} 110-\mathrm{O}^{2} 3^{\mathrm{i}}$ & $109.40(14)$ & $\mathrm{N} 4-\mathrm{C} 5-\mathrm{H} 5$ & 126.7 \\
\hline $\mathrm{N} 2-\mathrm{N} 1-\mathrm{H} 1$ & $120(2)$ & $\mathrm{O} 8-\mathrm{Cl} 6-\mathrm{O} 7$ & $109.84(12)$ \\
\hline $\mathrm{C} 5-\mathrm{N} 1-\mathrm{H} 1$ & $127(2)$ & $\mathrm{O} 8-\mathrm{Cl} 6-\mathrm{O}^{9 \mathrm{ii}}$ & $109.92(7)$ \\
\hline $\mathrm{C} 5-\mathrm{N} 1-\mathrm{N} 2$ & $111.94(17)$ & $\mathrm{O} 8-\mathrm{Cl} 6-\mathrm{O} 9$ & $109.92(7)$ \\
\hline $\mathrm{C} 3-\mathrm{N} 2-\mathrm{N} 1$ & $103.41(17)$ & $\mathrm{O} 9{ }^{\mathrm{ii}}-\mathrm{Cl} 6-\mathrm{O} 7$ & $108.77(8)$ \\
\hline $\mathrm{C} 3-\mathrm{N} 4-\mathrm{H} 4$ & $127(2)$ & $\mathrm{O} 9-\mathrm{Cl} 6-\mathrm{O} 7$ & $108.77(7)$ \\
\hline $\mathrm{C} 5-\mathrm{N} 4-\mathrm{H} 4$ & $126(2)$ & $\mathrm{O} 9 \mathrm{ii}-\mathrm{Cl} 6-\mathrm{O} 9$ & $109.60(12)$ \\
\hline $\mathrm{C} 5-\mathrm{N} 4-\mathrm{C} 3$ & $107.08(16)$ & & \\
\hline $\mathrm{N} 1-\mathrm{N} 2-\mathrm{C} 3-\mathrm{N} 4$ & $0.2(3)$ & $\mathrm{C} 5-\mathrm{N} 1-\mathrm{N} 2-\mathrm{C} 3$ & $0.2(3)$ \\
\hline $\mathrm{N} 2-\mathrm{N} 1-\mathrm{C} 5-\mathrm{N} 4$ & $-0.5(2)$ & $\mathrm{C} 5-\mathrm{N} 4-\mathrm{C} 3-\mathrm{N} 2$ & $-0.5(3)$ \\
\hline $\mathrm{C} 3-\mathrm{N} 4-\mathrm{C} 5-\mathrm{N} 1$ & $0.6(2)$ & & \\
\hline
\end{tabular}

Symmetry codes: (i) $x,-y+3 / 2, z$; (ii) $x,-y+1 / 2, z$.

Hydrogen-bond geometry $\left(\AA,{ }^{\circ}\right)$

\begin{tabular}{lllll}
\hline$D-\mathrm{H} \cdots A$ & $D-\mathrm{H}$ & $\mathrm{H} \cdots A$ & $D \cdots A$ & $D-\mathrm{H} \cdots A$ \\
\hline $\mathrm{N} 4-\mathrm{H} 4 \cdots \mathrm{O} 13$ & 0.818 & 2.141 & 2.921 & 159.61 \\
$\mathrm{~N} 1-\mathrm{H} 1 \cdots \mathrm{O} 9$ & 0.787 & 2.230 & 2.874 & 139.46 \\
$\mathrm{~N}-\mathrm{H} 1 \cdots \mathrm{O} 7$ & 0.787 & 2.407 & 2.936 & 125.59 \\
$\mathrm{~N} 4-\mathrm{H} 4 \cdots \mathrm{O} 8$ & 0.818 & 2.719 & 3.049 & 106.14 \\
\hline
\end{tabular}

